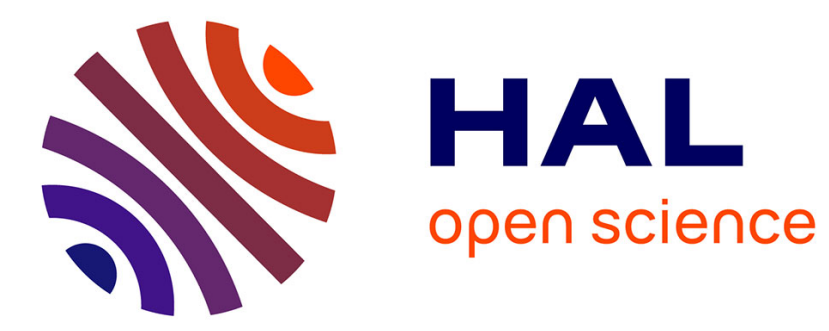

\title{
An analysis of growth rates and directions of growth of primary roots of field-grown banana trees in an andisol at three levels of soil compaction
}

François Lecompte, Harry Ozier-Lafontaine, Loïc Pages

\section{- To cite this version:}

François Lecompte, Harry Ozier-Lafontaine, Loïc Pages. An analysis of growth rates and directions of growth of primary roots of field-grown banana trees in an andisol at three levels of soil compaction. Agronomie, 2003, 23 (3), pp.209-218. 10.1051/agro:2002084 . hal-00886173

\section{HAL Id: hal-00886173 https://hal.science/hal-00886173}

Submitted on 1 Jan 2003

HAL is a multi-disciplinary open access archive for the deposit and dissemination of scientific research documents, whether they are published or not. The documents may come from teaching and research institutions in France or abroad, or from public or private research centers.
L'archive ouverte pluridisciplinaire HAL, est destinée au dépôt et à la diffusion de documents scientifiques de niveau recherche, publiés ou non, émanant des établissements d'enseignement et de recherche français ou étrangers, des laboratoires publics ou privés. 


\title{
An analysis of growth rates and directions of growth of primary roots of field-grown banana trees in an andisol at three levels of soil compaction
}

\author{
François LECOMPTE**, Harry OZIER-LAFONTAINE ${ }^{\mathrm{b}}$, Loïc PAGES ${ }^{\mathrm{a}}$ \\ ${ }^{a}$ INRA, Unité de recherche Plantes et Systèmes de culture Horticoles, Domaine Saint-Paul, Site Agroparc, 84914 Avignon Cedex 9, France \\ ${ }^{\mathrm{b}}$ INRA Centre Antilles-Guyane, Unité Agropédoclimatique de la Zone Caraïbe, Domaine Duclos, 97170 Petit-Bourg, Guadeloupe, France
}

(Received 11 December 2001; accepted 21 June 2002)

\begin{abstract}
In monocotyledons, soil exploration by the root system is mainly due to primary roots. Classical root observations, from soil cores or minirhizotrons, do not allow local root growth rates to be related directly to soil physical conditions around the roots. The pattern of growth of banana primary roots in an andisol under field conditions was determined by destructive, architecturally-based samplings of the root system over a four-month period at three levels of soil compaction. Primary root growth rates were estimated from morphological measurements, while soil porosity around growing roots was assessed by soil coring. In all treatments, root growth rates appeared to be variable with time, and a linear regression between the root growth rate and root apical diameter, soil porosity and the degree-day sum (base $14^{\circ} \mathrm{C}$ ) accounted for $92 \%$ of the observed variance. Primary root growth was reduced by nearly $40 \%$ in the most compacted soil. Above-ground plant growth was also affected after a few weeks. Primary root growth directions were not affected by soil compaction and roots appeared to curve toward the horizontal plane when ageing. These results highlight the variability of root growth in field conditions, even in uniform soil conditions, and suggest possibilities for the development of root growth models and models of root system architecture.
\end{abstract}

root growth rate / Musa acuminata / apical diameter / soil porosity / root growth directions

Résumé - Évaluation au champ des rythmes de croissance et des trajectoires des racines primaires du bananier, dans un sol à différents niveaux de compactage. Chez les monocotylédones, la colonisation du sol par le système racinaire est essentiellement due au développement des racines primaires. Les méthodes classiques d'évaluation de la croissance racinaire, à partir d'échantillons de sols ou d'observations en minirhizotrons, ne permettent pas de mettre directement en relation croissance des racines et contraintes physiques du sol. Les rythmes de croissance et les trajectoires des racines primaires du bananier dans un andosol ont été évaluées à partir d'échantillonnages destructifs pendant quatre mois dans les conditions de champ, à trois niveaux de compactage du sol. Les vitesses de croissance des racines primaires ont été estimées à partir d'observations morphologiques tandis que la porosité du sol autour des racines en croissance était mesurée à l'aide de prélèvements de sol au cylindre. La croissance des racines primaires est apparue variable dans le temps, quel que soit le traitement. Une régression multiple incluant les facteurs diamètre apical, porosité du sol et somme de degrés jours (seuil $14{ }^{\circ} \mathrm{C}$ ) a expliqué $92 \%$ de la variance observée dans les rythmes de croissance. La vitesse a été diminuée de $40 \%$ pour le compactage du sol le plus élevé. La croissance des parties aériennes a été également affectée, plus légèrement. Les trajectoires des racines n'ont pas été affectées par le compactage, et il est apparu que les racines ont tendance à s'incurver vers l'horizontale à mesure qu'elles vieillissent. Ces résultats mettent en évidence la variabilité de croissance des racines dans les conditions de champ, même lorsque le sol présente des caractéristiques physiques homogènes. Ils offrent également des perspectives en termes de modélisation de la croissance et de l'architecture des systèmes racinaires.

vitesse de croissance des racines / Musa acuminata / diamètre apical / porosité du sol / trajectoire des racines

\section{INTRODUCTION}

Soil colonization by a root system is the consequence of the appearance of primary roots, the growth and branching of these roots in various directions in the soil, and subsequent growth and branching of higher order laterals. In major monocotyledons, the root growth rates of primary roots (seminal primary roots arising from the seed and nodal primary roots arising from the stem) are several times higher than those of lateral roots (e.g. [8, 27, 36]). In banana, growth 
estimates from field observations showed that the mean growth rates of primary roots were 3.7 and 7.1 times higher than those of first and second order laterals, respectively [18]. Furthermore, lateral roots in monocotyledons usually live only for a few days $[13,27]$, while primary roots usually grow throughout the plant's life $[13,15]$. In monocotyledons, primary roots can therefore be considered as the most important roots in terms of root system spatial extension, even if the contribution of lateral roots to water and nutrient absorption is predominant [12, 39], because of their large surface area.

Tardieu and Manichon [34] have shown from root mapping in vertical soil profiles that soil colonization by the root system can be related to variation in soil structure in the ploughed layer. However, rooting patterns in response to soil conditions are usually evaluated by means of root length density measurements for the overall root system, either from soil cores $[9,28]$ or minirhizotrons [5, 10]. However, little attention has been paid to date to the variation in space and time of soil colonization by the main roots under varying soil conditions, in terms of root growth rates and direction of growth. For maize, it was inferred from field observations that primary roots from the first five internodes had declining elongation rates when ageing [26]. One explanation for this would be that carbohydrate supply to the root elongation zone was lower as the distance to the sources increased along with the number of competing sinks. However, it has been shown for several species that root growth in the field is correlated with carbon nutrition via light interception [2, 40]. Variable root growth rates also arise from variable soil conditions, notably soil strength $[17,21]$. However, if assimilate availability for the roots is not constant during the growing period, root growth responses to a given soil strength are also likely to be variable.

There are at least two ways to estimate root growth rates in undisturbed field conditions from root excavation. In the first method, used in the field by Pellerin and Pagès [27] and many other authors in laboratory conditions, the root growth rate is estimated by dividing root length by the time since root appearance. This calculation assumes that the root growth rate is constant for a given root. The other method is based on root growth rate estimation from the measurement of the length of the apical unbranched zone: the time necessary for a lateral primordium to emerge at the primary root surface has proved to be stable in a large range of environmental conditions $[1,18$, $24]$, so that the length of the apical unbranched zone bearing no lateral roots is linearly related to the root growth rate. It is therefore possible to evaluate root growth rates at various times during the growth cycle in relation to soil physical conditions around the roots and overall plant growth. Soil compaction is a severe problem with increasing axle loads used in farming. Currently, agriculture has a challenge to use water and nutrients as efficiently as possible. For optimum use of theses resources, knowledge of root growth changes of field-grown plants is crucial. This study focuses on the harmful effects of severe soil compaction on banana root growth dynamics. The pattern of primary root growth of banana trees in the field was investigated at various levels of soil compaction in an andisol.

\section{MATERIALS AND METHODS}

The experiment was carried out at the CIRAD-FLHOR experimental farm in Neufchâteau, in Guadeloupe, French West Indies ( $16^{\circ} 09^{\prime} \mathrm{N}, 61^{\circ} 16^{\prime} \mathrm{W}$, altitude $\left.485 \mathrm{~m}\right)$. It started on the 30th of November 1999 and ended on the 23rd March 2000. The soil was an Andisol, with a clayey texture (62\% clay, $32 \%$ loam, $6 \%$ sand), $6.7 \%$ organic matter, a CEC of $9.2 \mathrm{cmol}_{(+)} \cdot \mathrm{kg}^{-1}$ and a $\mathrm{pH}$ (water) of 6.28 .

\subsection{Soil preparation and compaction}

After the destruction and the burial of the standing vegetation, the soil was loosened with a single-tined subsoiler to a depth of approximately $45 \mathrm{~cm}$. The field was then subdivided into three plots of equal size for the compaction treatments. No replicates were made, i.e. we hypothesized that there was no environmental variability on the field scale other than the differences in physical characteristics arising from soil compaction. The soil was then compacted using the method described in Pietola and Smucker [28] with repeated passes of a tractor on the whole surface of the soil. The tractor was driven so that wheel tracks were contiguous across the subplots. Treatments were applied to the subplots as follows: one was left uncompacted (NC); one was compacted by 2 passes over the entire plot of a $3000 \mathrm{~kg}$ weight tractor, with a tyre pressure of $70 \mathrm{kPa}$ (medium compaction, $\mathrm{MC}$ ); the last was compacted by 5 passes of a heavier tractor $(5500 \mathrm{~kg})$ with a $1200 \mathrm{~kg}$ axle load and a tyre pressure of $200 \mathrm{kPa}$ (high compaction, HC). In both the MC and HC treatments, the tractor speed was $5 \mathrm{~km} \cdot \mathrm{h}^{-1}$. Gravimetric soil water content measured just before compaction was similar at 10 and $30 \mathrm{~cm}$ depth, i.e. 0.734 and $0.761 \mathrm{~g} \cdot \mathrm{g}^{-1}$, respectively, and higher at $60 \mathrm{~cm}$ depth, in the B horizon, with a mean value of $0.863 \mathrm{~g} \cdot \mathrm{g}^{-1}$. In both horizons, these moisture contents represented soil matric potentials ranging between -1 and $-10 \mathrm{kPa}$, i.e. moister than field capacity. As soil water content remained high in every treatment throughout the experiment (see below), soil shrinkage did not occur and the soil structure remained continuous throughout the ploughed zone. No cracks or channels appeared in the soil that could have influenced the direction of growth of main roots.

\subsection{Banana planting and sampling}

Young banana plants of cv Grande Naine (AAA genome, Cavendish subgroup), grown from tissue culture and hardened in a nursery for 6 weeks, were planted in each subplot on a $2.35 \mathrm{~m}$ square grid, at a density of 1890 plants $\cdot$ ha $^{-1}$. Each subplot contained 160 plants. Plants were rainfed and fertilized as follows: dolomitic limestone $\left(250 \mathrm{~kg} \cdot \mathrm{ha}^{-1}\right)$ and ammonium sulphate $\left(180 \mathrm{~kg} \cdot \mathrm{ha}^{-1}\right)$ were applied 6 and 13 days after planting, respectively; then an application of a N-P-K$\mathrm{Mg}\left(15-4-30-8,180 \mathrm{~kg} \cdot \mathrm{ha}^{-1}\right)$ fertilizer was carried out every 15 days. Weeds were controlled chemically, with gluphosinate (5 $1 \cdot \mathrm{ha}^{-1}, 150 \mathrm{~g} \cdot \mathrm{l}^{-1}$ gluphosinate ammonium) before planting and paraquat $\left(1.51 \cdot \mathrm{ha}^{-1}, 39 \%\right.$ paraquat dichloride) between the rows 1 month after planting. Soil moisture was monitored with tensiometers placed at 15,40 and $60 \mathrm{~cm}$ depth, with four replications at each depth for each treatment. Tensiometer measurements were appropriate since soil water potential 


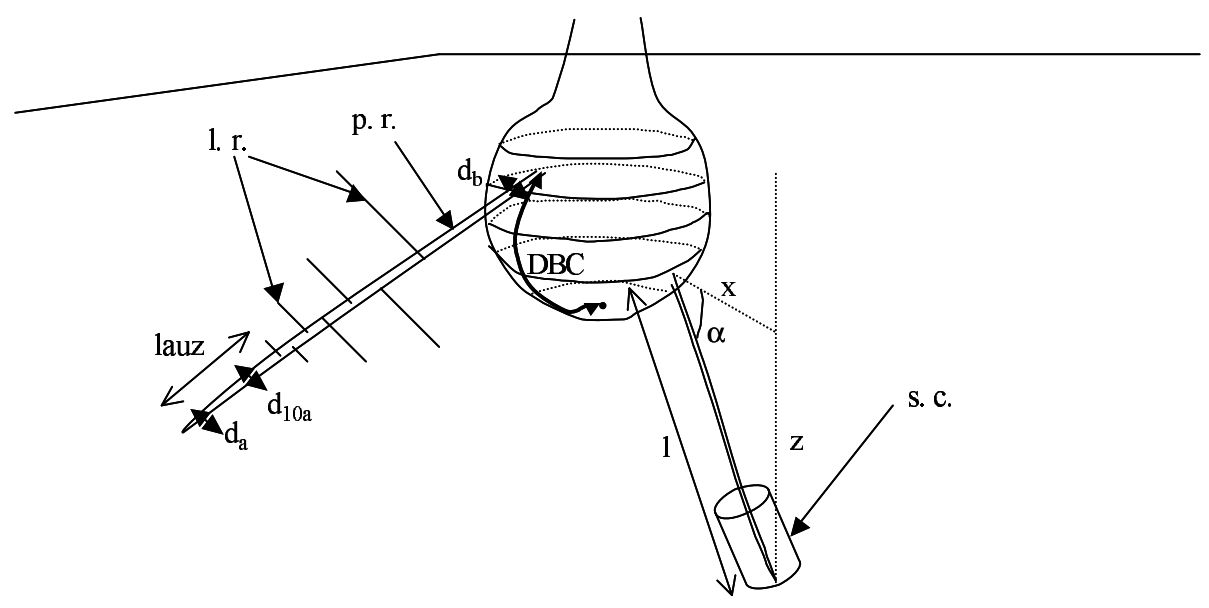

Figure 1. Schematic diagram showing the measurements made for each root. DBC $(\mathrm{cm})$ : distance to the base of the corm; 1: root length (cm); lauz: length of the apical unbranched zone $(\mathrm{cm}) ; \mathrm{x}(\mathrm{cm})$ : distance between the root apex and the base of the plant, on the horizontal plane; $\mathrm{z}(\mathrm{cm})$ : apex depth corrected for the root depth at the point of emergence on the corm; $\alpha\left(^{\circ}\right)$ : angle of root growth $\left(\alpha=\tan { }^{-1}(\mathrm{z} / \mathrm{x})\right)$; $\mathrm{d}_{\mathrm{a}}(\mathrm{mm})$ : root apical diameter; $d_{10 a}(\mathrm{~mm})$ : root diameter measured $10 \mathrm{~cm}$ away from the apex; $d_{b}(\mathrm{~mm})$ : root basal diameter. s.c.: soil core used for the measurement of soil physical characteristics around a growing root; 1.r.: lateral roots; p.r.: primary root.

remained high throughout the experiment. Air temperature, irradiance and rainfall were measured with an automated meteorological station connected to a data logger near the field. Mean daily air temperatures were almost constant between 22 and $24{ }^{\circ} \mathrm{C}$, with a slight decrease from the beginning to the end of the experiment, and a short period of time when the temperature ranged between $20^{\circ} \mathrm{C}$ and $22^{\circ} \mathrm{C}$ (days 47 to 51 after planting). Degree-day sums were calculated using a base temperature of $14^{\circ} \mathrm{C}$. Daily irradiance varied, but mean values for 5-day periods were more uniform, around $30 \mathrm{~mol} \cdot \mathrm{m}^{-2} \cdot$ day $^{-1}$ from days 1 to 19 and 61 to 115 after planting, and $25 \mathrm{~mol} \cdot \mathrm{m}^{-2} \cdot \mathrm{day}^{-1}$ from days 20 to 60 after planting.

Five plants per treatment, randomly chosen in each subplot, were used to measure changes in the number of leaves and the total leaf area per plant. Measurements were made at 15-day intervals. Another sample was used for destructive shoot and root measurements: four series of excavations (P1 to P4) were done for each subplot at monthly intervals. For each subplot at each sampling time, three banana trees were sampled. A total of 3 (replicates) $\times 3$ (treatments) $\times 4$ (sampling dates) $=$ 36 plants were used. Except for the first series with very young plants, it took a day to excavate one plant and to sample its root system, so that for each treatment at each time a series of excavations lasted between 3 and 6 days. For each plant, four to six randomly selected primary roots and samples of their lateral root system were completely separated from the surrounding soil, from the base to the proximal end of the apical unbranched zone. Only primary roots were considered in this study. A diagram illustrating the various measurements is shown in Figure 1. As plants were derived from tissue culture, the primary root system was only composed of nodal roots which had emerged from the corm. Primary roots were cut off at their base, near the corm, and marked on both sides for a further examination of their insertion position on the corm. When a root was almost completely excavated, i.e. around $5 \mathrm{~cm}$ beyond the proximal end of the apical unbranched zone, the apical part was collected together with an undisturbed soil sample: a cylindrical soil core $(10 \mathrm{~cm} \times$ $4.2 \mathrm{~cm}$ ) was driven into the soil surrounding the root, following the root's course, and with the root axis centered in the middle of the core, so that the main part of the apical unbranched zone was included in the core. The core and, if present, the few centimeters of the extreme apical part of the root that were remaining in the soil, were collected, and the position of the apex was noted. The angle between the root line and the horizontal plane was calculated as $\alpha=\operatorname{arctg}(\mathrm{z} / \mathrm{x})$ where $\mathrm{z}(\mathrm{cm})$ is the depth of the apex and $\mathrm{x}(\mathrm{cm})$ the horizontal distance to the pseudostem base.

Roots whose apical meristem had decayed, where thick intermediate roots called relaying roots [18] had appeared, were discarded. A total of 134 primary roots were kept for growth analysis. Soil sampling around growing roots sometimes failed or was not possible. This happened when the root apex was too superficial or too close to the plant base to insert a soil core; when the soil around the apex was unintentionally removed during excavation; when the root apex was not included in the core because the expected root growth direction did not correspond to the actual direction, or when the apical zone was not as long as expected, resulting in too short a root section inside the core. As a result, the number of available cores used for growth analysis did not correspond to the total number of roots studied. Table I gives the number of roots and cores sampled at each date in each treatment. Root growth direction was assessed on a further subsample. On 15 randomly selected roots (5 per treatment) at the fourth excavation date, the position of the distal part of these root fragments, expressed as the horizontal distance to the base of the plant (coordinate $\mathrm{x}$ ) and the depth (coordinate $\mathrm{z}$ ) was noted to define the direction of root growth.

\subsection{Plant, root and soil measurements}

Sampled plants were separated into leaves, pseudo-stem and corm. The fresh and dry masses of each organ and the leaf 
Table I. Number of roots and soil cores used for growth analysis on each date in each treatment. HC: high compaction, MC: moderate compaction, NC: no compaction.

\begin{tabular}{|c|c|c|c|c|c|c|c|c|c|c|}
\hline \multirow[b]{3}{*}{ Treatment } & \multicolumn{8}{|c|}{ Sampling date } & \multirow{2}{*}{\multicolumn{2}{|c|}{ total }} \\
\hline & \multicolumn{2}{|c|}{ P1 } & \multicolumn{2}{|c|}{$\mathrm{P} 2$} & \multicolumn{2}{|c|}{ P3 } & \multicolumn{2}{|c|}{$\mathrm{P} 4$} & & \\
\hline & roots & soil cores & roots & soil cores & roots & soil cores & roots & soil cores & roots & soil cores \\
\hline $\mathrm{HC}$ & 9 & 5 & 12 & 6 & 10 & 7 & 12 & 5 & 43 & 18 \\
\hline MC & 12 & 6 & 12 & 6 & 11 & 5 & 13 & 4 & 48 & 21 \\
\hline $\mathrm{NC}$ & 10 & 6 & 13 & 5 & 8 & 4 & 12 & 7 & 43 & 22 \\
\hline
\end{tabular}

areas were measured. The total number of primary roots per corm was counted. For each sampled root, the position on the corm, expressed as the curvilinear distance over the surface of the corm from its base to the point of root insertion, hereafter called "distance to the base of the corm" (DBC) was measured [19]. Also measured for each root were (Fig. 1): the total length, the basal diameter, the apical diameter, the diameter $10 \mathrm{~cm}$ away from the apex and the length of the apical unbranched zone. The apical diameter was measured at onethird of the total distance between the apex and the base of the apical cone; for primary roots, the point of measurement was positioned between $0.7 \mathrm{~mm}$ and $1.4 \mathrm{~mm}$ away from the apex. The root growth rate was estimated for each root as a linear function of the length of the apical unbranched zone. Details of this estimation are given by Lecompte et al. [18]. Briefly, it is considered that both the time required for the initiation of a lateral root primordia and the time required for its development until its emergence at the bearing root surface are constant. As a result, the distance separating the bearing root apex and its most distal lateral root is proportional to its growth rate. The fresh and dry mass of the soil sample collected in the core were measured, from which were calculated the volumetric soil water content $\left(\theta, \mathrm{cm}^{3} \cdot \mathrm{cm}^{-3}\right)$ and its dry bulk density $\left(\gamma_{\mathrm{d}}, \mathrm{g} \cdot \mathrm{cm}^{-3}\right)$. When calculating bulk density, soil volume in the core was not corrected for the presence of the root apex, while soil mass was calculated after taking away the root fragment. However, root volume (around $\left.5 \mathrm{~cm}^{3}\right)$ was low compared with the core volume $\left(518 \mathrm{~cm}^{3}\right)$, so bulk densities were only slightly underestimated, by around $1 \%$. From the soil core were also calculated the total porosity $(\%)$ :

$$
\mathrm{n}=100 \times\left[1-\left(\gamma_{\mathrm{d}} / \gamma_{\mathrm{s}}\right)\right]
$$

and the air-filled porosity (\%):

$$
\mathrm{n}_{\mathrm{a}}=100 \times\left[1-\left(\gamma_{\mathrm{d}} / \gamma_{\mathrm{s}}\right)-\left(\theta \times\left(\gamma_{\mathrm{d}} / \gamma_{\mathrm{w}}\right)\right)\right]
$$

where $\gamma_{\mathrm{s}}$ is the soil particle density $\left(\gamma_{\mathrm{s}}=2.41 \mathrm{Mg} \cdot \mathrm{m}^{-3}\right.$, calculated by Dorel et al. [11] in the same field), $\gamma_{\mathrm{w}}$ the water density $\left(\gamma_{\mathrm{w}}=1\right)$.

\subsection{Data analysis}

Due to unequal sample sizes in the different treatments and dates (Tab. I), analysis of variance and means were computed with specific functions suitable for unbalanced designs. Means were compared using the Tukey-Kramer procedure, an extension of Tukey's Honest Significance Difference (HSD), at the $95 \%$ level of significance. The effects of treatments, soil depth (data were grouped into 3 classes of soil depths, 0$15 \mathrm{~cm}, 15-30 \mathrm{~cm}$ and $30-45 \mathrm{~cm}$ ) and sampling date on soil water content and porosity were tested. Analysis of variance was also performed to assess the effects of root DBC and soil compaction on root apical diameter. The various effects of plant and soil factors on primary root growth variability were then studied.

\section{RESULTS}

\subsection{Soil measurements}

Soil water potentials between $15 \mathrm{~cm}$ and $60 \mathrm{~cm}$ depth remained between -5 and $-25 \mathrm{kPa}$ throughout the experiment in all treatments, except during a 10-day period with low rainfall between days 89 and 99 after planting. This period corresponded to the time lag between the third and the fourth sampling series. At the end of this period, soil water potential at $15 \mathrm{~cm}$ had fallen to $-29 \mathrm{kPa}$ in the $\mathrm{NC}$ treatment, $-37 \mathrm{kPa}$ in the $\mathrm{MC}$ treatment, and $-53 \mathrm{kPa}$ in the $\mathrm{HC}$ treatment. Lower soil water potentials might have been reached near the soil surface for a few days. Volumetric soil water content increased with soil compaction, as shown in Table II. There

Table II. Means \pm standard deviations of volumetric water content $\left(\mathrm{cm} \cdot \mathrm{cm}^{-3}\right)$, total and air-filled soil porosity $(\%)$, measured in soil cores sampled around growing roots, for each treatment. HC: high compaction, MC: moderate compaction, NC: no compaction. Different letters within the same row indicate significant differences at 5\% (HSD test) $(\mathrm{n}=18-22$ depending on treatment).

\begin{tabular}{lccc}
\hline & & Treatment & HC \\
& $\mathrm{NC}$ & $\mathrm{MC}$ & $0.58 \pm 0.03 \mathrm{c}$ \\
Volumetric water content $\left(\mathrm{cm}^{3} \cdot \mathrm{cm}^{-3}\right)$ & $0.48 \pm 0.03 \mathrm{a}$ & $0.54 \pm 0.05 \mathrm{~b}$ & $66.15 \pm 1.69 \mathrm{~b}$ \\
Total porosity (\%) & $71.91 \pm 2.34 \mathrm{a}$ & $67.73 \pm 2.34 \mathrm{~b}$ & $8.41 \pm 4.26 \mathrm{c}$ \\
Air-filled porosity (\%) & $23.75 \pm 2.31 \mathrm{a}$ & $14.01 \pm 7.23 \mathrm{~b}$ & \\
\hline
\end{tabular}




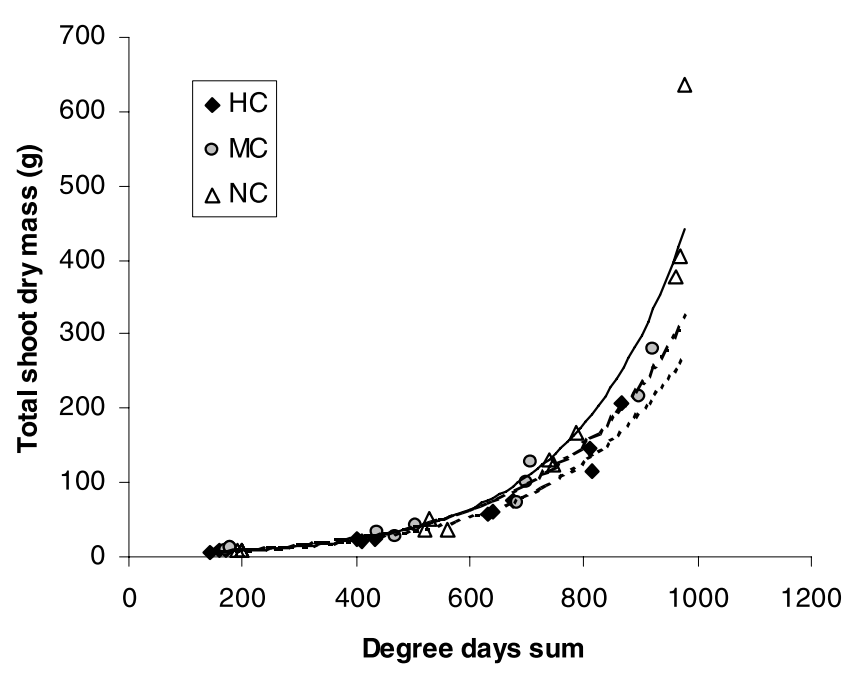

Figure 2. Evolution of total shoot dry mass (leaves + pseudo stem + corm, g) with degree-day sum (with a $14{ }^{\circ} \mathrm{C}$ base temperature), for each treatment. $\mathrm{HC}$ : high compaction, $\mathrm{MC}$ : moderate compaction, NC: no compaction. Lines are exponential functions fitted to the data: —: NC, - - : MC, -----: HC.

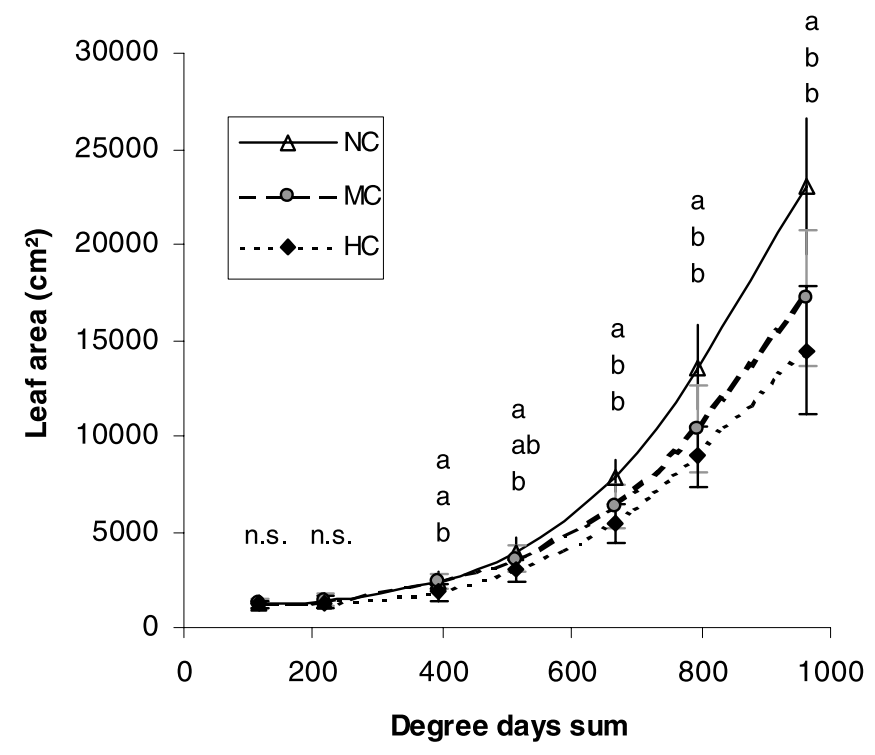

Figure 3. Evolution of plant leaf area $\left(\mathrm{cm}^{2}\right)$ with degree-day sum (with a $14{ }^{\circ} \mathrm{C}$ base temperature), for each treatment. HC: high compaction, MC: moderate compaction, NC: no compaction. Means and standard errors for 5 plants are given at each date. Different letters above the points indicate significant differences (HSD test at $5 \%$ ) between treatments. The upper letter is for NC, the letter in the middle for $\mathrm{MC}$, the lower letter for $\mathrm{HC}$.

were, however, in a given treatment, no significant differences in soil water content at different depths or sampling dates. Overall mean soil bulk density increased from $0.66( \pm 0.04)$ in $\mathrm{NC}$ to $0.77( \pm 0.06)$ in $\mathrm{MC}$ and $0.82( \pm 0.03)$ in HC. Table II shows that soil compaction significantly affected both total and air-filled porosity. Total soil porosity was only slightly affected, with a reduction of, respectively, $6 \%$ and $8 \%$ in $\mathrm{MC}$ and $\mathrm{HC}$ compared with NC. There were no significant

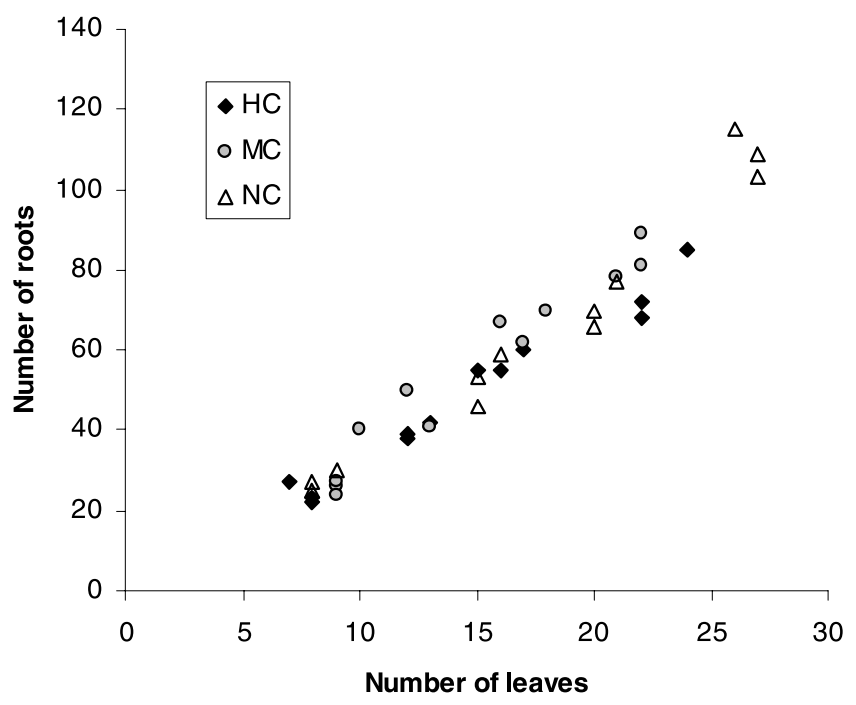

Figure 4. Number of roots versus number of leaves in the different treatments. HC: high compaction, MC: moderate compaction, NC: no compaction.

differences in total porosity in MC and $\mathrm{HC}$. Air-filled porosity was much more reduced, by $41 \%$ and $64 \%$ in $\mathrm{MC}$ and $\mathrm{HC}$, respectively. As for soil water content, the effect of soil depth and sampling date on soil total and air-filled porosity was not significant.

\subsection{Plant growth and root emission}

The growth of total above-ground dry mass followed an exponential function of degree-day sum (Fig. 2). The trend was similar in all treatments; however, growth was faster in NC than in MC and NC. Significant differences were found between leaf areas in $\mathrm{NC}$ and the other treatments from about 400 degree-days to the end of the experiment (Fig. 3). This was at least partly due to a slower rate of leaf appearance in the compacted treatments: an average of 1.5 additional leaves was noted in NC compared with $\mathrm{HC}$ on the last measurement date. The number of roots was highly correlated to the number of leaves (Fig. 4); however, an analysis of covariance showed that the slope was significantly less steep in $\mathrm{HC}$ compared with MC and NC.

\subsection{Root apical diameters and growth rates}

Root apical diameters were analyzed from the root positions on the corm and the treatments (Tab. III). The mean apical diameter in all treatments increased with DBC. As DBC increased with plant age [19], this means that apical diameter was higher for late-emerging roots. An analysis of variance showed a positive effect of the DBC factor on root apical diameter $(P<0.0001)$, but no significant effect of either the treatment $(P=0.5)$ or the interaction treatment $\times$ DBC $(P=$ $0.31)$. The overall mean root growth rates were 1.58 $( \pm 0.52) \mathrm{cm} \cdot$ day $^{-1}, \quad 1.83( \pm 0.61) \quad \mathrm{cm} \cdot \mathrm{day}^{-1}$ and 2.52 $( \pm 0.77) \mathrm{cm} \cdot$ day $^{-1}$, in $\mathrm{HC}, \mathrm{MC}$ and $\mathrm{NC}$, respectively. Using these mean values, and based on root emergence rates in the 
Table III. Means \pm standard deviations of primary root apical diameters $(\mathrm{mm})$, by classes of distances $(\mathrm{cm})$ to the base of the corm and by treatments. The distance to the base of the corm is the curvilinear distance between the base of the corm and the point of emergence of the root. HC: high compaction, MC: moderate compaction, NC: no compaction ( $\mathrm{n}=2-23$ depending on the DBB class and the treatment).

\begin{tabular}{lccccccc}
\hline & \multicolumn{6}{c}{ Distance to the base of the corm $(\mathrm{DBC}, \mathrm{cm})$, by classes } \\
\cline { 2 - 7 } Treatment & $0-1 \mathrm{~cm}$ & $1-2 \mathrm{~cm}$ & $2-3 \mathrm{~cm}$ & $3-4 \mathrm{~cm}$ & $4-5 \mathrm{~cm}$ & $5-6 \mathrm{~cm}$ & $6-7 \mathrm{~cm}$ \\
\hline $\mathrm{HC}$ & $1.07 \pm 0.89$ & $1.19 \pm 0.17$ & $1.49 \pm 0.28$ & $1.63 \pm 0.27$ & $1.42 \pm 0.31$ & $1.6 \pm 0.21$ & - \\
$\mathrm{MC}$ & $0.71 \pm 0.41$ & $1.27 \pm 0.21$ & $1.29 \pm 0.23$ & $1.57 \pm 0.27$ & $1.42 \pm 0.23$ & $1.56 \pm 0.42$ & $1.83 \pm 0.32$ \\
$\mathrm{NC}$ & - & $1.08 \pm 0.2$ & $1.33 \pm 0.38$ & $1.43 \pm 0.31$ & $1.61 \pm 0.28$ & $1.8 \pm 0.23$ & $2 \pm 0.32$ \\
Means & $0.89 \pm 0.6$ & $1.19 \pm 0.2$ & $1.37 \pm 0.29$ & $1.55 \pm 0.28$ & $1.45 \pm 0.26$ & $1.71 \pm 0.29$ & $1.86 \pm 0.2$ \\
\hline
\end{tabular}

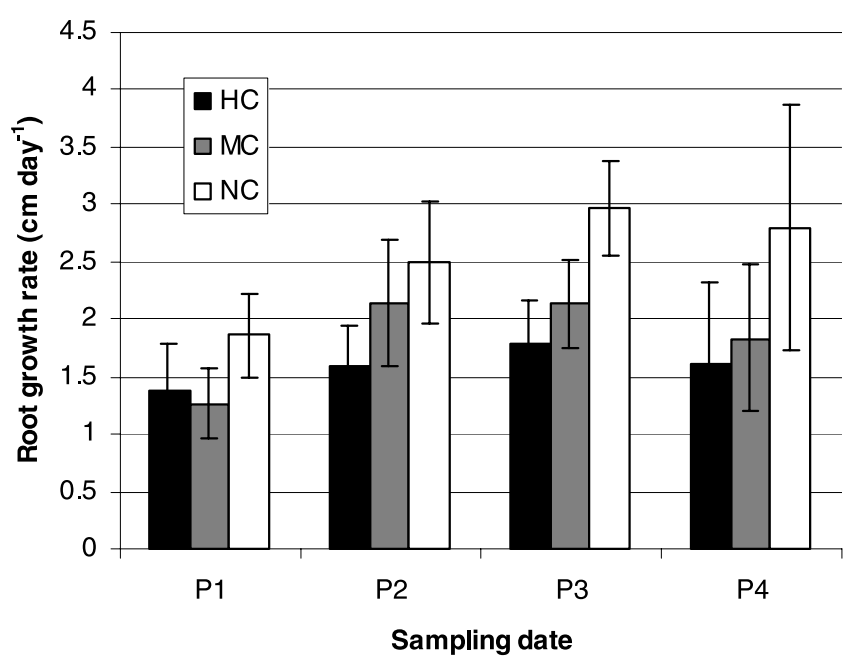

Figure 5. Mean root growth rates $\left(\mathrm{cm} \cdot\right.$ day $\left.^{-1}\right)$ and standard deviations on each sampling date (P1 to $\mathrm{P} 4)$ for each treatment. $\mathrm{HC}$ : high compaction, $\mathrm{MC}$ : moderate compaction, $\mathrm{NC}$ : no compaction ( $\mathrm{n}$ as given in Tab. I).

different treatments, a total primary root length per plant at the end of the experiment ( 970 degree-days) of $123 \mathrm{~m}, 88 \mathrm{~m}$ and $69 \mathrm{~m}$ was estimated for the $\mathrm{NC}, \mathrm{MC}$ and $\mathrm{HC}$ treatments, respectively. Mean root growth rates per sampling date were also affected by soil compaction (Fig. 5). There were significant differences between NC and the other treatments on all dates. Differences between MC and $\mathrm{HC}$ were only significant for the second sampling date, P2. Mean root growth rates in all treatments increased from $\mathrm{P} 1$ to $\mathrm{P} 3$, and decreased thereafter. There was a significant relationship between root apical diameter and root growth rate, as illustrated in Figure 6. The maximum observed root growth rate increased with root apical diameter. Therefore, an envelope curve, fitted by an asymptotic exponential function (also called monomolecular function) could be fitted to the data, and allowed the maximum growth rate reached by a root of a given apical diameter to be estimated. As the overall mean apical diameter increased from P1 to P4 (respectively, $1.24 \mathrm{~mm}, 1.34 \mathrm{~mm}, 1.43 \mathrm{~mm}$ and $1.52 \mathrm{~mm}$ ), part of the increase in root growth rates between sampling dates observed in Figure 5 was due to higher mean apical diameters. However, in every treatment, the ratio between the actual root growth rate (estimated from root LAUZ) and potential root

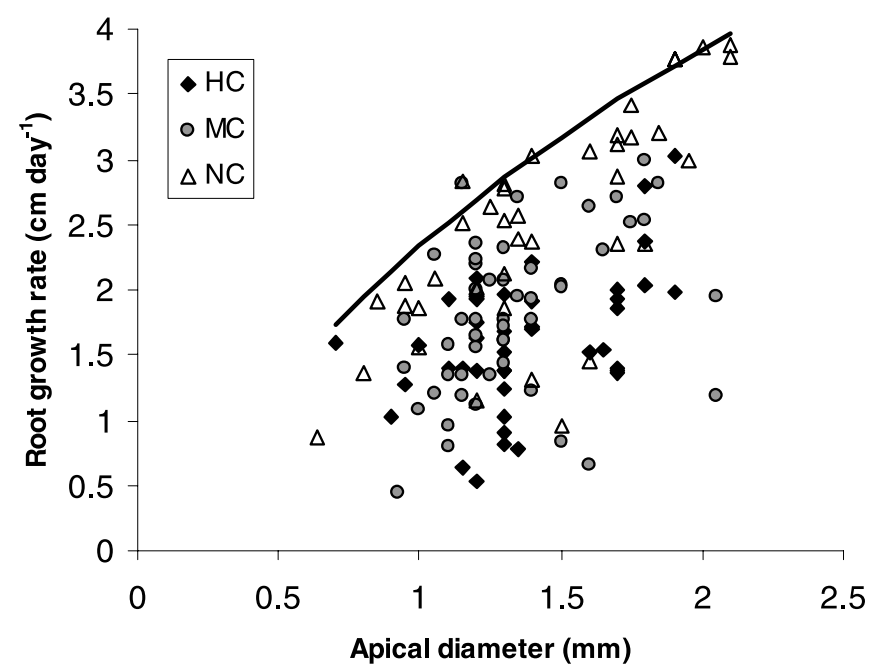

Figure 6. Primary root growth rate $\left(\mathrm{cm} \cdot \mathrm{day}^{-1}\right)$ versus apical diameter $(\mathrm{mm})$. Data are separated between treatments: HC: high compaction, MC: moderate compaction, NC: no compaction. The 98th percentile of root growth rate was calculated for 14 classes of increasing (with a $0.1 \mathrm{~mm}$ increment) apical diameter. The envelope curve is a monomolecular function fitted to these 14 points. Equation: PGR $=\alpha \times(1-\exp (\beta \times \mathrm{AD}))$, where PGR $\left(\mathrm{cm} \cdot \mathrm{day}^{-1}\right)$ is the potential growth rate, $\mathrm{AD}$ the apical diameter $(\mathrm{mm})$, and and fitted parameters. Calculated values of $\alpha$ and $\beta$ are 5.06 and -0.65 , respectively.

growth rate (estimated from the apical diameter) increased from P1 to P3 and decreased in P4 (Tab. IV). An analysis of variance showed no significant effect of the root apical diameter, nor of the root DBC on this ratio (data not shown). Therefore, at any compaction level and whatever the root age or position on the plant, the difference between the actual and potential growth rate decreased with time from planting to the third sampling date. Actual root growth rates in $\mathrm{P} 4$ were smaller than in P3 while mean potential growth rates were higher due to higher apical diameters.

The effect of local soil total porosity measured with the soil cores around root elongation zones was studied. Root growth rate $(y)$ increased with both root apical diameter (x1), soil total porosity (x2) and degree-day sum at the time of excavation (x3) as follows:

$\mathrm{y}=-6.0+1.02 \mathrm{x} 1+9.22 \times 2+0.007 \times 3 \quad\left(\mathrm{r}^{2}=0.92, P<0.001\right)$. 
Table IV. Means and standard deviations of the ratios of the root growth rate $\left(\mathrm{cm} \cdot\right.$ day $\left.^{-1}\right)$ on the potential root growth rate $\left(\mathrm{cm} \cdot \mathrm{day}{ }^{-1}\right)$, for each sampling date (P1 to P4) and treatment. Potential root growth rate is calculated as a monomolecular function of the root apical diameter. HC: high compaction, MC: moderate compaction, NC: no compaction (n as given in Tab. I).

\begin{tabular}{lccccc}
\hline & \multicolumn{4}{c}{ Sampling date } \\
\cline { 2 - 6 } Treatment & P1 & P2 & P3 & $0.54 \pm 0.16$ \\
HC & $0.45 \pm 0.15$ & $0.59 \pm 0.13$ & $0.63 \pm 0.1$ & $0.51 \pm 0.18$ & $0.58 \pm 0.21$ \\
MC & $0.46 \pm 0.11$ & $0.71 \pm 0.16$ & $0.76 \pm 0.11$ & $0.52 \pm 0.19$ & 0.62 \\
NC & $0.70 \pm 0.15$ & $0.83 \pm 0.15$ & $0.92 \pm 0.11$ & $0.82 \pm 0.27$ & $0.81 \pm 0.19$ \\
\hline
\end{tabular}

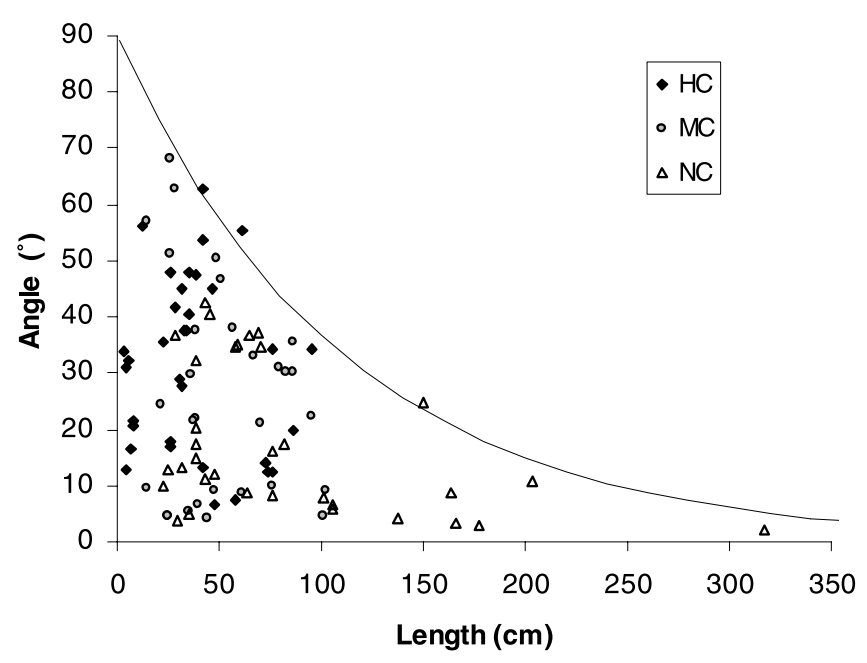

Figure 7. Root angle $\left({ }^{\circ}\right)$ to the horizontal as a function of root length $(\mathrm{cm})$ in the different treatments. HC: high compaction, MC: moderate compaction, NC: no compaction. Root angle is calculated as the angle between the horizontal line and the line joining the pseudo stem base to the root apex. The line is an envelope curve fitted by a decreasing exponential function.

\subsection{Root shape}

Root shape was affected by soil compaction. In the HC and MC treatments, roots were frequently flattened along one plane. This resulted in differences of up to $50 \%$ between root diameters measured $10 \mathrm{~cm}$ away from the apex, depending on the side measured. When this occurred, the root diameter was calculated as the mean between the shortest and the largest diameter. Overall mean root diameters at $10 \mathrm{~cm}$ away from the apex were $4.34( \pm 1.3), 3.69( \pm 1.2)$ and $3.51( \pm 1.1)$ for $\mathrm{HC}$, MC and NC, respectively. These differences were not significant at the $5 \%$ level. In NC there was a close relationship $\left(r^{2}=0.71\right)$ between the diameters measured at the apex and $10 \mathrm{~cm}$ away from the apex. This relationship was weak, but still significant in $\mathrm{MC}\left(\mathrm{r}^{2}=0.21\right)$ and $\mathrm{HC}\left(\mathrm{r}^{2}=0.34\right)$.

\subsection{The direction of root growth}

The angle between the root line and the horizontal plane decreased with root length (Fig. 7). Whereas short roots after emergence grew in any direction, roots during their elongation tended, whatever the compaction applied, to curve toward the horizontal plane. This phenomenon also appeared when examining individual roots' direction of growth (Fig. 8). Some roots

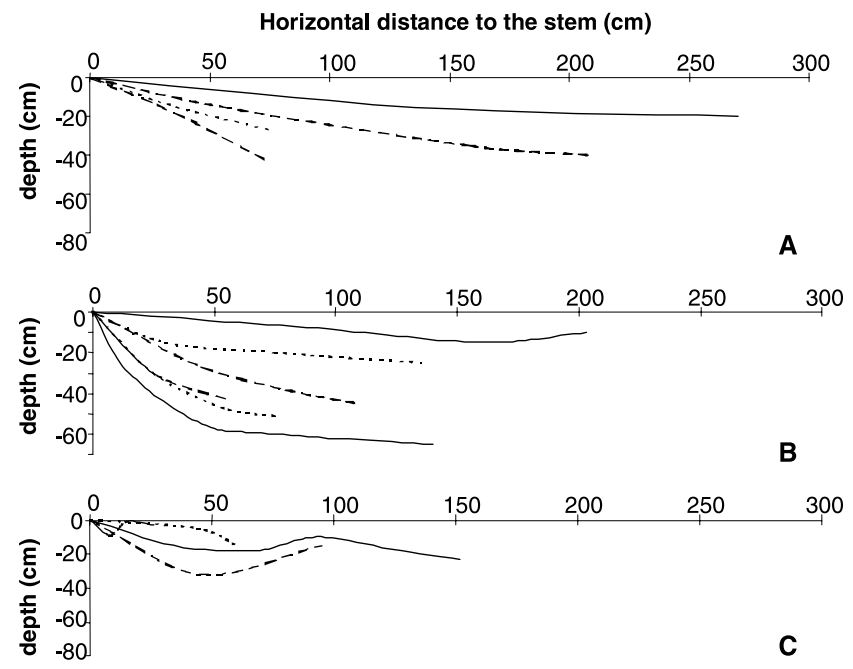

Figure 8. Examples of root growth trajectories on a two-dimensional plane. 3 types of trajectories are represented: A: straight lines; $\mathrm{B}$ : trajectories curved toward the horizontal; C: trajectories with more than one inflection point. : NC, - -: MC, -----: HC.

grew roughly in a straight line (Fig. 8a); nearly half followed a curved track (Fig. 8b), while a few roots grew along more erratic courses (Fig. 8c). For each root in the whole sample, the ratio of the root length to the distance between the root emergence point and the position of the apex (i.e. $\left(x^{2}+z^{2}\right)^{1 / 2}$ ) was calculated. Values ranged between 1 (no deviation) and 2.93. The mean values were $1.38 \pm 0.45,1.32 \pm 0.37$ and $1.28 \pm 0.25$ for $\mathrm{HC}, \mathrm{MC}$ and $\mathrm{NC}$, respectively. These differences were not significant, and were mainly due to a few roots in the $\mathrm{MC}$ and HC treatments that were strongly aberrant (ratio value between 2 and 3). An analysis of variance performed on the calculated ratio indicated a significant effect of root length, but no effects of the treatments. Roots growing in the compacted soils were therefore no more aberrant than roots growing in uncompacted soil. However, roots were highly tortuous in the compacted treatments, with frequent very small curvatures along a few millimeters of the root, which were not taken into account in the root length measurements.

\section{DISCUSSION}

\subsection{Effects of soil compaction}

Andisols are known to have quite low bulk densities, even when compacted, and present a low compressibility at high 
water content [22]. However, Dorel et al. [11] have shown in the same soil as that used in this study that soil compaction due to mechanization strongly decreased soil macroporosity. The uncompacted soil bulk density of $0.66 \mathrm{Mg} \cdot \mathrm{m}^{-3}$ reported here is typical of such soils, and soil compaction by repeated wheelings increased bulk density up to $0.82 \mathrm{Mg} \cdot \mathrm{m}^{-3}$. Compared with NC, primary root growth was decreased by $27 \%$ and $37 \%$ in MC and HC, respectively. Significant effects of soil compaction on root length at such low bulk densities have been reported by Misra and Gibbons [23] on eucalypt seedling-roots. Compaction resulted in a large decrease in soil air-filled porosity. Measurements of soil dry bulk density or porosity alone cannot provide information on the stress responsible for the decrease in root growth rate, either mechanical impedance and/or soil hypoxia. Even though soil resistance was not directly measured, there was evidence from morphological observations in the compacted treatments that roots were affected by mechanical impedance: root cortex thickening and irregularity of root shape are classical responses to increasing soil strength $[4,6]$. However, when considering the mean root distal diameters in the different subplots, root thickening measured some centimeters away from the apex appeared to be moderate. The consequences of the decrease in air-filled porosity on oxygen availability for the root are more difficult to assess. Air-filled porosity in the highly compacted soil was low, $0.08 \mathrm{~cm} \cdot \mathrm{cm}^{-3}$; this value is close to the upper limit under which anoxia can occur [7]. However, the critical oxygen pressure under which root respiration is affected varies between plant species, and it has been shown in several studies $[16,29]$ that the cortex of banana primary roots consists of an aerenchyma which could facilitate root respiration at low oxygen pressures. There were no apparent symptoms of hypoxia on roots growing in the compacted soils, and soil water potentials remained under $-5 \mathrm{kPa}$ in all treatments. Indirect observations therefore lead to the idea that root and plant growth responses to soil compaction were more likely to be due to an increase in mechanical impedance than to a lack of soil aeration.

\subsection{Root development and plant growth}

Dry mass accumulation was slightly higher in NC than in $\mathrm{MC}$ and HC. Leaf area and root number per plant were also reduced in the compacted treatments, but significant differences appeared only several weeks after planting. Similar results were found for maize by Tardieu and Manichon [34]: both root and shoot dry matter were significantly affected by compaction after only a few weeks. Misra and Gibbons [23] have noted a lack of shoot response to soil compaction after a 17-day experiment on young eucalypt seedlings. However, roughly constant relative differences in root growth rates between treatments were observed, while root emission was only slightly lower in the compacted treatments. Thus, significant differences in total primary root length probably appeared only a few days after planting. It is therefore likely that poor root development in the compacted treatment after planting resulted in a delayed reduction in shoot development after a few weeks. There are many instances in the literature showing that limited root development can reduce water and nutrient absorption and limit crop growth (e.g. [5, 31, 33]), especially when the concentration of immobile nutrients becomes too low. It has also been shown that plant roots can 'sense' soil strength directly and produce signals that reduce the leaf expansion rate without altering stomatal conductance $[20,41]$. However, limited soil compaction may also increase plant growth due to a better root-soil contact and an increase in soil unsaturated hydraulic conductivity [3]. Lateral root growth can also compensate for reduced primary root growth. There are thus several, possibly interacting reasons that may explain the observed reduced shoot growth.

\subsection{Root growth rates}

We have shown in this study that the primary root growth rate is not constant with time, so that estimations of growth rates from total root length and age must be interpreted with caution as they give estimates of mean root growth rates. The methods used in this study, combining root growth rate estimates with local soil porosity measurements around growing roots, allowed us to evaluate root growth variability in space and time. Whatever the level of soil compaction, three main factors accounted for $92 \%$ of the variability of observed growth rates: the root apical diameter, soil total porosity and degree-day sum. The relationship between root diameter and growth rate has often been reported [18, 25, 37] and the increase in mean root growth rates from planting to three months after planting was partly due to a higher mean root apical diameter in the samples, as roots emitted later in plant development were thicker. However, there was also an increase in the ratio between actual and potential root growth rates, independent of root diameter or age. This increase in root growth rates stopped during the fourth month after planting. In maize, Pellerin and Pagès [27] noted from total length measurements that root elongation rates tended to decrease with thermal time. They suggested that either carbon supply to the longest roots might have been limited or that reduced root growth rates were due to unfavorable soil physical conditions in the deepest soil layers. In our study, whatever the soil compaction, the root system remained shallow, and both soil water content and bulk density showed small fluctuations throughout the experiment. Air and soil temperature remained unchanged during the period, and significant variations in mean daily irradiance were limited to a short period between the first and the second sampling date. It is therefore likely that these time-dependent variations in root growth rate were mediated by plant internal regulation rather than by a change in environmental conditions, and it can be hypothesized that variations in assimilate availability and distribution between sinks were responsible for such changes. Several studies $[1,26]$ mention the hypothesis that the root elongation rate could decrease with root length due to a greater distance of the root meristem from the sources and enhanced competition between the sinks. There was no evidence in this experiment that, for a given treatment, longer roots had slower elongation rates than shorter ones, and there was no effect of root length on the ratio between the actual and potential growth rate. However, conclusions about this hypothesis would require that all roots had the same apical diameter, and we have shown that younger roots had larger apical diameters than older ones. Furthermore, a possible evolution of root 
apical diameters with root length could not be assessed in this study based on destructive sampling. Nevertheless, these results emphasize the fact that roots of a given diameter in definite soil physical conditions can show a range of growth responses, depending on overall plant regulation. This regulation is taken into account in the most recent models of root system architecture [30, 38], in which assimilates are evenly distributed among the different root sinks as a fixed proportion of each root's growth potential multiplied by an impedance factor depending on local soil strength. Following this hypothesis, the decrease in root growth rates on the fourth sampling date could arise from a preferential assimilate allocation to the suckers (whose growth started between P3 and $\mathrm{P} 4$ ) and/or to the reproductive organs, which start growing at around 1000 degree-days.

\subsection{Root growth direction}

Our study showed that most banana primary roots tended to become more and more horizontal with time, as root angle to the horizontal plane appeared to decrease with root length. Observations of root courses confirmed this general pattern, and many roots changed course towards the horizontal. Different results were found with maize [35], for which it was shown that nearly $50 \%$ of the roots tended to turn towards the vertical. In our study, changes in direction appeared at various depths and distances from the plant. Uniform compaction resulted in the absence of a porosity gradient with depth in each treatment in the ploughed zone, i.e. up to $45 \mathrm{~cm}$ depth. More than $90 \%$ of the roots excavated remained in this zone. This agrees with other results on bananas [32] and plantains [14] which show that root system development was essentially superficial; this seems to be characteristic in the Musa genus. Changes in root directions were evaluated by dividing the actual root length by the distance between the root emergence point on the corm and the position of the apex. This ratio takes into account either vertical or horizontal components of the deviation. The treatments had no significant influence on this ratio, indicating that roots were no more devious in the compacted treatments than in the not compacted ones. In the compacted treatments, compaction resulted in massive soil structures, with hardly any large pores in which roots could change direction to find more favorable growth conditions. As soil water content remained high in all treatments, the formation of soil cracks did not occur. Therefore roots in the compacted treatments had to grow through these massive structures, becoming flattened and tortuous. Compaction had little or no effect on more gradual root bending, but provoked small-scale deviations, resulting in highly localized tortuosity.

\section{CONCLUSION}

This study has shown that banana root development in andisols can be severely reduced by soil compaction, with damaging effects on overall plant growth. The use of a morphological indicator to evaluate the root growth rate, coupled with soil porosity measurements, appeared to be useful for a dynamic analysis of soil colonization by the root system. Primary root growth rates appeared to be variable during plant development, quite apart from the effect of soil local growth conditions,. In this soil and climate, the primary root growth rate could be described accurately with only a few parameters, and these results offer interesting prospects for root growth modeling.

Acknowledgements: The authors wish to thank Hubert Manichon and Marc Dorel for fruitful discussions on the methods, André Jabot and the staff of the CIRAD-FLHOR for their technical support, and Thierry Bajazet and Simon Leinster for their help with field data collection.

\section{REFERENCES}

[1] Aguirrezabal L.A.N., Tardieu F., An architectural analysis of the elongation of field grown sunflower root systems. Elements for modelling the effects of temperature and intercepted radiations, J. Exp. Bot. 47 (1996) 411-420.

[2] Aguirrezabal L.A.N., Deleens E., Tardieu F., Root elongation rate is accounted for by intercepted PPFD and source-sink relations in field and laboratory grown sunflower, Plant Cell Environ. 17 (1994) 443-450.

[3] Arvidsson J., Nutrient uptake and growth of barley as affected by soil compaction, Plant and Soil 208 (1999) 9-19.

[4] Atwell B.J., Physiological responses of lupin roots to soil compaction, Plant and Soil 111 (1988) 277-281.

[5] Barraclough P.B., Weir A.H., Effects of a compacted subsoil layer on root and shoot growth, water use and nutrient uptake of winter wheat, J. Agric. Sci. 110 (1988) 207-216.

[6] Bennie A.T.P., Growth and mechanical impedance, in: Waisel Y., Eshel A., Kafkafi U. (Eds.), Plant roots: the hidden half, 2nd ed., Marcel Dekker, New York, 1996, pp. 453-470.

[7] Boone F.R., Van der Werf H.M.G., Kroesbergen B., Ten Hag B.A., Boers A., The effect of compaction in arable layer in sandy soil on the growth of maize for sillage. I. Critical matric water potentials in relation to soil aeration and mechanical impedance, Neth. J. Agric. Sci. 34 (1986) 155-171.

[8] Cahn M.D., Zobel R.W., Bouldin D.R., Relationship between root elongation rate and diameter and duration of growth of lateral roots of maize, Plant and Soil 119 (1989) 271-279.

[9] Chassot A., Stamp P., Richner W., Root distribution and morphology of maize seedlings as affected by tillage and fertilizer placement, Plant and Soil 231 (2001) 123-135.

[10] De Ruijter F.J., Veen B.W., Van Oijen M., A comparison of soil core sampling and minirhizotrons to quantify root development of field-grown potatoes, Plant and Soil 182 (1996) 301-312.

[11] Dorel M., Roger-Estrade J., Manichon H., Delvaux B., Porosity and soil-water properties of Caribbean volcanic ash soils, Soil Use Manage. 17 (2000) 1-18.

[12] Fitter A.H., Stickland T.R., Harvey M.L., Wilson G.W., Architectural analysis of plant root systems. I. Architectural correlates of exploitation efficiency, New Phytol. 118 (1991) 375382 .

[13] Fusseder A., The longevity and activity of the primary root of maize, Plant and Soil 101 (1987) 257-265.

[14] Irizarry H., Vicente-Chandler J., Silva S., Root distribution of plantains growing on five soil types, J. Agric. Uni. Puerto Rico 65 (1981) 29-34.

[15] Klepper B., Root growth and water uptake, in: Stewart B.A., Nielsen D.R. (Eds.), Irrigation of agricultural crops, Agricultural monograph, Vol. 30, ASA-CSSA, Madison, 1990, pp. 280-322.

[16] Kwa M., Architecture, morphogenèse et anatomie de quelques cultivars de bananiers, Ph.-D. Thesis, Université de Montpellier II, Sciences et techniques du Languedoc,1993, 295 p.

[17] Laboski C.A.M., Dowdy R.H., Allmaras R.R., Lamb J.A., Soil strength and water content influences on corn root distribution in a sandy soil, Plant and Soil 203 (1998) 239-247. 
[18] Lecompte F., Ozier-Lafontaine H., Pagès L., The relationship between static and dynamic variables in the description of root growth. Consequences for field interpretation of rooting variability, Plant and Soil 236 (2001) 19-31.

[19] Lecompte F., Vaucelle A., Pagès L., Ozier-Lafontaine H., Number, position, diameter and initial growth direction of primary roots in Musa, Ann. Bot. 90 (2002) 43-51.

[20] Masle J., Passioura J.B., The effect of soil strength on the growth of young wheat plants, Aust. J. Plant Physiol. 14 (1987) 643-656.

[21] Materechera S.A., Mloza-Banda H.R., Soil penetration resistance, root growth and yield of maize as influenced by tillage system on ridges of Malawi, Soil Till. Res. 41 (1997) 13-24.

[22] Mc Nabb D.H., Boersma L., Evaluation of the relationship between compressibility and shear strength of andisols, Soil Sci. Soc. Am. J. 57 (1993) 923-929.

[23] Misra R.K., Gibbons A.K., Growth and morphology of eucalypt seedling-roots, in relation to soil strength arising from compaction, Plant and Soil 182 (1996) 1-11.

[24] Mollier A., Pellerin S., Maize root system growth and development as influenced by phosphorus deficiency, J. Exp. Bot. 50 (1999) 487-497.

[25] Pagès L., Growth pattern of the lateral roots of young oak (Quercus robur) tree seedlings. Relationship with apical diameter, New Phytol. 130 (1995) 503-509.

[26] Pagès L., Pellerin S., Evaluation of parameters describing the root system architecture of field grown maize plants (Zea mays L.). II. Density, length and branching of first order lateral roots, Plant and Soil 164 (1994) 169-176.

[27] Pellerin S., Pagès L., Evaluation of parameters describing the root system architecture of field grown maize plants (Zea mays L.). I. Elongation of seminal and nodal roots and extension of their branched zone, Plant and Soil 164 (1994) 155-167.

[28] Pietola L., Smucker A.J.M., Fibrous carrot root responses to irrigation and compaction of sandy and organic soils, Plant and Soil 200 (1998) 95-105.

[29] Riopel J.L., Steeves T.A., Studies on the root of Musa acuminata cv Gros Michel. I. The anatomy and development of main roots, Ann. Bot. 28 (1964) 475-495.
[30] Somma F., Hopmans J.W., Clausnitzer V., Transient threedimensional modelling of soil water and solute transport with simultaneous root growth, root water and nutrient uptake, Plant and Soil 202 (1998) 281-293.

[31] Stirzaker R.J., Passioura J.B., Wilms Y., Soil structure and plant growth: impact of bulk density and biopores, Plant and Soil 185 (1996) 151-162.

[32] Summerville W.A.T., Root distribution of the banana, Qld. Agric. J. 52 (1939) 376-392.

[33] Tardieu F., État structural, enracinement et alimentation hydrique du maïs. III. Disponibilité des réserves en eau du sol, Agronomie 7 (1987) 279-288.

[34] Tardieu F., Manichon H., État structural, enracinement et alimentation hydrique du maïs. II. Croissance et disposition spatiale du système racinaire, Agronomie 7 (1987) 201-211.

[35] Tardieu F., Pellerin S., Trajectory of the nodal roots of maize in fields with low mechanical constraints, Plant and Soil 124 (1990) 39-45.

[36] Tennant D., Root growth in wheat. I. Early patterns of multiplication and extension of wheat roots including effects of level of nitrogen, phosphorus and potassium, Aust. J. Agric. Res. 27 (1976) 183-197.

[37] Thaler P., Pagès L., Root apical diameter and root elongation rate of rubber seedlings (Hevea brasiliensis) show parallel responses to photoassimilate availability, Physiol. Plant. 97 (1996) 365-371.

[38] Thaler P., Pagès L., Why are laterals less affected than main axes by homogenous unfavorable physical conditions? A model based hypothesis, Plant and Soil 217 (1999) 151-157.

[39] Varney G.T., Canny M.J., Rates of water uptake into the mature root system of maize plants, New Phytol. 123 (1993) 775-786.

[40] Vincent C.D., Gregory P.J., Effects of temperature on the development and growth of winter wheat roots. II. Field studies of temperature, nitrogen and irradiance, Plant and Soil 119 (1989) 99-110.

[41] Young I.M., Montagu K., Conroy J., Bengough A.G., Mechanical impedance of root growth directly reduces leaf elongation rates of cereals, New Phytol. 135 (1997) 613-619. 